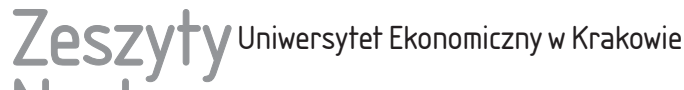 Naukowe
}

\section{Ryzyko starości a dodatkowy system emerytalny w Polsce}

\section{Streszczenie}

W opracowaniu poruszono problematykę zabezpieczania przed ryzykiem starości przez dodatkowy system emerytalny w Polsce. W toku przeprowadzonych analiz weryfikacji poddano hipotezę mówiącą, że w celu skutecznego zarządzania ryzykiem starości w Polsce niezbędne jest wprowadzenie zmian w funkcjonowaniu instrumentów trzeciego filara systemu emerytalnego. W tym celu w pierwszej kolejności scharakteryzowano ryzyko starości oraz omówiono zasady funkcjonowania instrumentów trzeciego filara. Następnie przeprowadzono analizę aktualnego zakresu wykorzystania tych instrumentów. W rezultacie stwierdzono, że nie ma podstaw do odrzucenia postawionej hipotezy, co stało się podstawą do wskazania pożądanych kierunków zmian w zakresie funkcjonowania tych instrumentów. Ponadto podkreślono również wagę edukacji emerytalnej społeczeństwa.

Słowa kluczowe: system emerytalny, stopa zastąpienia, luka emerytalna, trzeci filar. Klasyfikacja JEL: H55, J32, E21.

\section{Wprowadzenie}

Wyzwaniem stojącym przed współczesnymi systemami emerytalnymi jest skuteczne zabezpieczanie przed ryzykiem starości w jego zarówno indywidualnym, jak i ogólnospołecznym aspekcie. W Polsce po reformie przeprowadzonej w 1999 r. zadanie to zostało rozłożone pomiędzy bazową (obowiązkową) oraz dodatkową (dobrowolną) część systemu emerytalnego. Rezultaty różnych analiz

Tomasz Jedynak, Uniwersytet Ekonomiczny w Krakowie, Katedra Zarządzania Ryzykiem i Ubezpieczeń, 31-510 Kraków, ul. Rakowicka 27, e-mail: tomasz.jedynak@uek.krakow.pl 
jednoznacznie wskazują, że w przypadku osób objętych reformą emerytury z części bazowej systemu będą kształtowały się na stosunkowo niskim poziomie, a ich wysokość nie będzie zapewniała osiągnięcia oczekiwanej stopy zastąpienia (np. [EUC 2012, OECD 2013]). W tej sytuacji szczególnego znaczenia nabierają dodatkowe formy oszczędzania na emeryturę funkcjonujące w ramach trzeciego filara systemu emerytalnego. Sytuacja ta skłoniła autora do podjęcia problemu badawczego, który może zostać sformułowany w postaci pytania: „czy instrumenty dostępne obecnie $w$ ramach trzeciego filara skutecznie zabezpieczają przed ryzykiem starości?". Określony w ten sposób problem badawczy leży u podstaw postawionej hipotezy, zgodnie z którą w celu skutecznego zarządzania ryzykiem starości niezbędne jest wprowadzenie zmian w funkcjonowaniu instrumentów trzeciego filara polskiego systemu emerytalnego. Mając na uwadze potrzebę weryfikacji tej hipotezy, za główne cele opracowania przyjęto charakterystykę ryzyka starości oraz analizę obecnych zasad funkcjonowania i zakresu wykorzystania instrumentów trzeciego filara. Ponadto celem opracowania jest również wskazanie potencjalnych kierunków zmian w zakresie funkcjonowania tych instrumentów.

\section{Ryzyko starości}

Złożoność zagadnień związanych z ryzykiem w naukach ekonomicznych powoduje, że w zależności od przyjętej perspektywy formułowane są definicje akcentujące różne aspekty tego pojęcia. Ryzyko bywa definiowane przez pryzmat: niepewności [Knight 1921, Willet 1951, Arrow 1979], niebezpieczeństwa [Philip 1967, Rowe 1977], możliwości osiągnięcia wyniku innego niż oczekiwany [Williams, Smith i Young 2002], prawdopodobieństwa straty [Skov 1991] oraz prawdopodobieństwa uzyskania wyniku innego niż oczekiwany [Czekaj i Dresler 2006]. Ryzyko starości, w zależności od rozważającego je podmiotu, również może być różnie postrzegane. Jednostka będzie traktować ryzyko starości jako niepewność dożycia określonego wieku (np. powszechnego wieku emerytalnego) bądź niebezpieczeństwo dożycia wieku, w którym nie będzie w stanie uzyskiwać dochodu z pracy. Z punktu widzenia całego systemu emerytalnego oraz instytucji stanowiących jego składowe ryzyko starości to przede wszystkim prawdopodobieństwo, że określona kohorta wiekowa będzie żyła dłużej lub krócej niż oczekiwana dla niej przeciętna długość trwania życia.

W klasycznym modelu ryzyka starości zaproponowanym przez T. Szumlicza ryzyko to dzieli się na dwie fazy. Pierwsza faza - faza oszczędzania, związana jest z możliwością dożycia wieku emerytalnego, a druga - faza konsumpcji, z możli- 
wością zbyt długiego życia na emeryturze [Szumlicz 2005, s. 10]. Fazy te zostały syntetycznie scharakteryzowane w tabeli 1 .

Tabela 1. Charakterystyka faz ryzyka starości

\begin{tabular}{|c|c|c|}
\hline Czynnik wyróżniający & $\begin{array}{c}\text { Faza I } \\
\text { (oszczędzanie) }\end{array}$ & $\begin{array}{c}\text { Faza II } \\
\text { (konsumpcja) }\end{array}$ \\
\hline Początek fazy & $\begin{array}{l}\text { Rozpoczęcie aktywności } \\
\text { zawodowej }\end{array}$ & $\begin{array}{l}\text { Rozpoczęcie pobierania } \\
\text { świadczeń emerytalnych }\end{array}$ \\
\hline Koniec fazy & $\begin{array}{l}\text { Zaprzestanie aktywności } \\
\text { zawodowej }\end{array}$ & Śmierć \\
\hline Obszar ryzyka & Dożycie wieku emerytalnego & $\begin{array}{l}\text { Długość życia po rozpoczęciu } \\
\text { pobierania świadczeń emery- } \\
\text { talnych }\end{array}$ \\
\hline $\begin{array}{l}\text { Problemy w konstrukcji sys- } \\
\text { temu emerytalnego }\end{array}$ & $\begin{array}{l}\text { Zasady gromadzenia oszczęd- } \\
\text { ności (uprawnień) emerytal- } \\
\text { nych } \\
\text { Zasady nabywania świadczeń } \\
\text { emerytalnych }\end{array}$ & $\begin{array}{l}\text { Zasady ustalania wysokości } \\
\text { wypłaty świadczeń emerytal- } \\
\text { nych }\end{array}$ \\
\hline $\begin{array}{l}\text { Przykładowe produkty finan- } \\
\text { sowe mające zastosowanie } \\
\text { w dodatkowych systemach } \\
\text { emerytalnych }\end{array}$ & $\begin{array}{l}\text { Fundusze inwestycyjne, lokaty } \\
\text { bankowe, ubezpieczenia na } \\
\text { dożycie, ubezpieczenia na } \\
\text { życie z funduszem kapitało- } \\
\text { wym }\end{array}$ & Ubezpieczenia rentowe \\
\hline
\end{tabular}

Źródło: opracowanie własne na podstawie [Szumlicz 2005, s. 10].

Szczegółowe rozważania nad problematyką ryzyka starości prowadzą do wyróżnienia kilku powiązanych z nim specyficznych rodzajów ryzyka (por. tabela 2). Należy przy tym zaznaczyć, że ryzyko dożycia wieku emerytalnego oraz ryzyko długowieczności odwołują się bezpośrednio do modelu faz ryzyka starości. Ryzyko emerytalne związane jest bezpośrednio z funkcjonowaniem systemów emerytalnych (bazowych i dobrowolnych). Ryzyko niedołęstwa starczego oraz ryzyko ubóstwa wywołanego starością leżą natomiast w obszarze zainteresowania polityki społecznej i zasadniczo nie stanowią przedmiotu rozważań ekonomii systemów emerytalnych.

Z perspektywy podjętej w opracowaniu problematyki funkcjonowania dodatkowego systemu emerytalnego ryzyko starości odnosi się przede wszystkim do sytuacji, w której poziom życia jednostki, która zaprzestała aktywności zawodowej i rozpoczęła pobieranie świadczeń emerytalnych, ulega istotnemu pogorszeniu. Tak rozumiane ryzyko starości jest więc związane z uzyskiwaniem przez jednostkę niższej niż oczekiwana stopy zastąpienia. 
Tabela 2. Wybrane rodzaje ryzyka towarzyszące starości

\begin{tabular}{|l|l|}
\hline \multicolumn{1}{|c|}{ Rodzaj ryzyka } & \multicolumn{1}{c|}{ Charakterystyka } \\
\hline $\begin{array}{l}\text { Ryzyko dożycia } \\
\text { wieku emerytalnego }\end{array}$ & $\begin{array}{l}\text { Ryzyko związane z osiągnięciem przez jednostkę wieku uprawniającego do } \\
\text { otrzymywania świadczeń emerytalnych. O ile jednostka postrzega dożycie } \\
\text { wieku emerytalnego jako zjawisko pozytywne, to dla rachunku aktuarial- } \\
\text { nego systemu emerytalnego jest to zdarzenie o charakterze negatywnym, } \\
\text { gdyż powoduje konieczność wypłacania świadczeń emerytalnych [Poteraj } \\
\text { 2011, s. 185] }\end{array}$ \\
\hline $\begin{array}{l}\text { Ryzyko długo- } \\
\text { wieczności }\end{array}$ & $\begin{array}{l}\text { Z indywidualnego punktu widzenia ryzyko długowieczności polega na } \\
\text { dożyciu przez jednostkę wieku dłuższego niż oczekiwany. Zagregowane } \\
\text { ryzyko długowieczności sprowadza się do sytuacji, w której średnia dłu- } \\
\text { gość życia całej kohorty wiekowej jest większa niż pierwotnie zakładano. } \\
\text { Jest to zatem ryzyko niewłaściwego oszacowania przeciętnej długości } \\
\text { trwania życia dla danej populacji lub poszczególnych jej roczników [Szcze- } \\
\text { pański 2014, s. 733] }\end{array}$ \\
\hline Ryzyko emerytalne & $\begin{array}{l}\text { Ryzyko to jest definiowane jako ryzyko uzyskania przez jednostkę niższej } \\
\text { niż pożądana stopy zastąpienia [Handshke, Łyskawa i Ratajczak 2005, } \\
\text { s. 148, za: Rutecka 2012, s. 24]. Ryzyko to dotyczy problemu adekwatności } \\
\text { świadczeń emerytalnych i sprowadza się do możliwości otrzymywania zbyt } \\
\text { niskiego świadczenia emerytalnego }\end{array}$ \\
\hline $\begin{array}{l}\text { Ryzyko niedołęstwa } \\
\text { starczego }\end{array}$ & $\begin{array}{l}\text { Ryzyko to sprowadza się do niezdolności osób starszych do samodzielnego } \\
\text { funkcjonowania. Jako takie dotyczy ono przede wszystkim kondycji psy- } \\
\text { chofizycznej, a nie sytuacji majątkowej }\end{array}$ \\
\hline $\begin{array}{l}\text { Ryzyko ubóstwa } \\
\text { wywołanego sta- } \\
\text { rością }\end{array}$ & $\begin{array}{l}\text { Ryzyko polegające na braku środków finansowych na zaspokojenie podsta- } \\
\text { wowych potrzeb życiowych przy jednoczesnym braku możliwości zarobko- } \\
\text { wania. Podobnie jak ryzyko niedołęstwa starczego ryzyko to z reguły jest } \\
\text { przedmiotem polityki społecznej państwa [Poteraj 2011, s. 185] }\end{array}$ \\
\hline
\end{tabular}

Źródło: opracowanie własne.

\section{Dodatkowe systemy emerytalne w zabezpieczaniu przed ryzykiem starości}

W perspektywie makroekonomicznej system emerytalny jest narzędziem podziału bieżącego PKB między pokolenie pracujące i pokolenie emerytów. Rozmiary tak rozumianego systemu emerytalnego stanowią efekt konsensusu społecznego i są wyznaczane przez wielkość części PKB, która nie służy wynagradzaniu czynników produkcji, lecz jest przekazywana na konsumpcję pokolenia niepracującego [Góra 2003, s. 62]. Z punktu widzenia jednostki - uczestnika systemu, system emerytalny powinien być natomiast traktowany jako narzędzie wyrównania (wygładzania) poziomu konsumpcji w całym okresie życia [Barr i Diamond 2014, s. 32] czy też alokacji dochodu w cyklu życia [Góra 2003, s. 51]. Podstawowym celem funkcjonowania tak rozumianych systemów emerytalnych 
jest zapewnienie ich uczestnikom dochodów w okresie po zakończeniu przez nich aktywności zawodowej [Góra 2003, s. 37; Szczepański 2014, s. 734]. W szerszym ujęciu cele funkcjonowania systemów emerytalnych obok wyrównania poziomu konsumpcji w cyklu życia oraz zaspokojenia potrzeb bytowych ludzi starszych obejmują również pomoc dla ubogich oraz redystrybucję dochodów. Ponadto wskazuje się, że polityka emerytalna może realizować również dodatkowe cele ekonomiczne i społeczne, takie jak np. wzrost gospodarczy [Barr i Diamond 2014, s. 37].

Cele stawiane systemom emerytalnym mogą być realizowane na różne sposoby, z wykorzystaniem zróżnicowanych metod finansowania i przez różne podmioty [Handshke, Łyskawa i Ratajczak 2005, s. 147]. Najpowszechniejszą formą realizacji tych celów są organizowane przez państwo powszechne (bazowe) systemy emerytalne. Uczestnictwo w tych systemach jest na ogół obowiązkowe, a uzyskiwane w ich ramach świadczenia są gwarantowane przez skarb państwa. Zmiany społeczno-gospodarcze, w tym w szczególności postępujący proces starzenia się społeczeństw, powodują jednak, że finanse publiczne większości państw są w coraz większym stopniu obciążone wydatkami związanymi z funkcjonowaniem tych systemów. Sytuacja ta sprawia, że w wielu krajach wdrażane są obecnie rozwiązania mające na celu z jednej strony zmniejszenie nierównowagi finansowej systemów emerytalnych, $\mathrm{z}$ drugiej zaś strony zapewnienie obywatelom skutecznego zabezpieczenia przed ryzykiem starości. Do rozwiązań tych należą m.in.: podnoszenie wieku emerytalnego, likwidacja przywilejów emerytalnych, zaostrzanie warunków uprawniających do uzyskania minimalnej emerytury bądź przejścia na wcześniejszą emeryturę czy też obniżanie relatywnej wysokości świadczeń. Ponadto w obliczu niewydolności obowiązkowych systemów emerytalnych szczególnego znaczenia nabierają również dobrowolne (dodatkowe) formy zabezpieczenia emerytalnego.

Analizując funkcjonowanie dodatkowych form zabezpieczenia emerytalnego, w pierwszej kolejności należy określić poziom pokrycia potrzeb obywateli przez emerytury zapewniane przez obowiązkowy system emerytalny. Niższa od pożądanej oczekiwana wysokość świadczeń z obowiązkowego systemu emerytalnego stanowi bowiem warunek sine qua non funkcjonowania systemów dodatkowych. Powszechnie stosowaną miarą pokrycia potrzeb obywateli przez emerytury zapewniane przez obowiązkowy system emerytalny jest stopa zastąpienia. Szacunkowe wartości tej miary w wybranych krajach OECD dla osób uzyskujących przeciętne wynagrodzenie przedstawiono na rys. 1. Miarą służącą temu samemu celowi jest również tzw. luka emerytalna. Na potrzeby analizy, podobnie jak autorzy raportu OECD Pensions at a Glance 2013 [OECD 2013, s. 193] oraz J. Rutecka [2014, s. 45], lukę emerytalną zdefiniowano jako różnicę pomiędzy stopą zastąpienia brutto zapewnianą przez obowiązkowy system emerytalny 


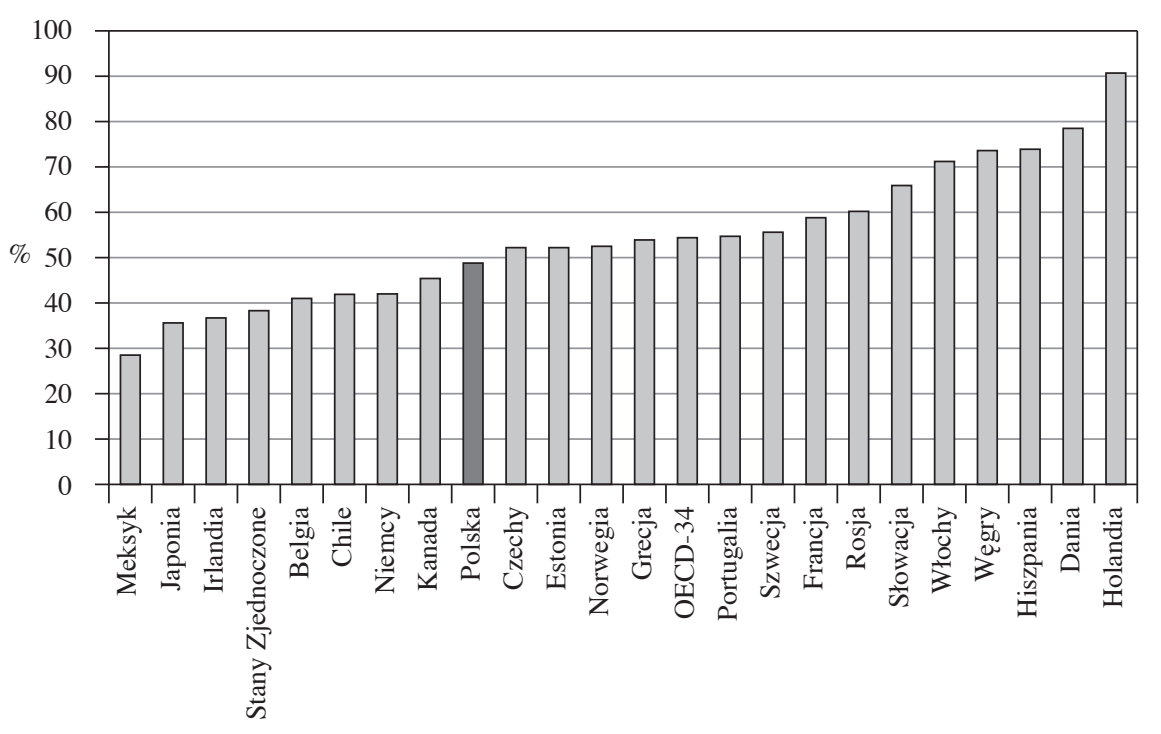

Rys. 1. Stopa zastąpienia w wybranych krajach OECD

Źródło: opracowanie własne na podstawie [OECD 2013, s. 193].

osobie zarabiającej średnie wynagrodzenie a średnią stopą zastąpienia obliczoną dla wszystkich krajów OECD $(54,4 \%)$. Wysokość luki emerytalnej w wybranych krajach OECD przedstawiono na rys. 2.

W tym miejscu odnotować należy, że zastosowana uproszczona metoda ustalania wysokości luki emerytalnej daje jedynie przybliżony obraz rzeczywistości, a jej wartość poznawcza jest ograniczona. Interpretując tę miarę, trzeba w szczególności wziąć pod uwagę następujące kwestie:

- dla jednostek podejmujących decyzję o dodatkowym oszczędzaniu na emeryturę istotna jest wielkość indywidualnej luki emerytalnej, która zależy od potrzeb i oczekiwań konkretnej osoby [Rutecka 2012, s. 46];

- zastosowany sposób ustalania luki emerytalnej nie uwzględnia różnic w poziomie zamożności oraz w sposobach realizacji polityki społecznej w różnych państwach;

- uzyskane wartości luki emerytalnej zostały obliczone jako średnia wartość dla uczestników powszechnych systemów emerytalnych. Ze względu na postępujące zmiany demograficzne obecnie systemy te są jednak reformowane, czego konsekwencją w większości krajów europejskich będzie pogłębianie się luki emerytalnej w przyszłości [EUC 2012, s. 96-99]. 


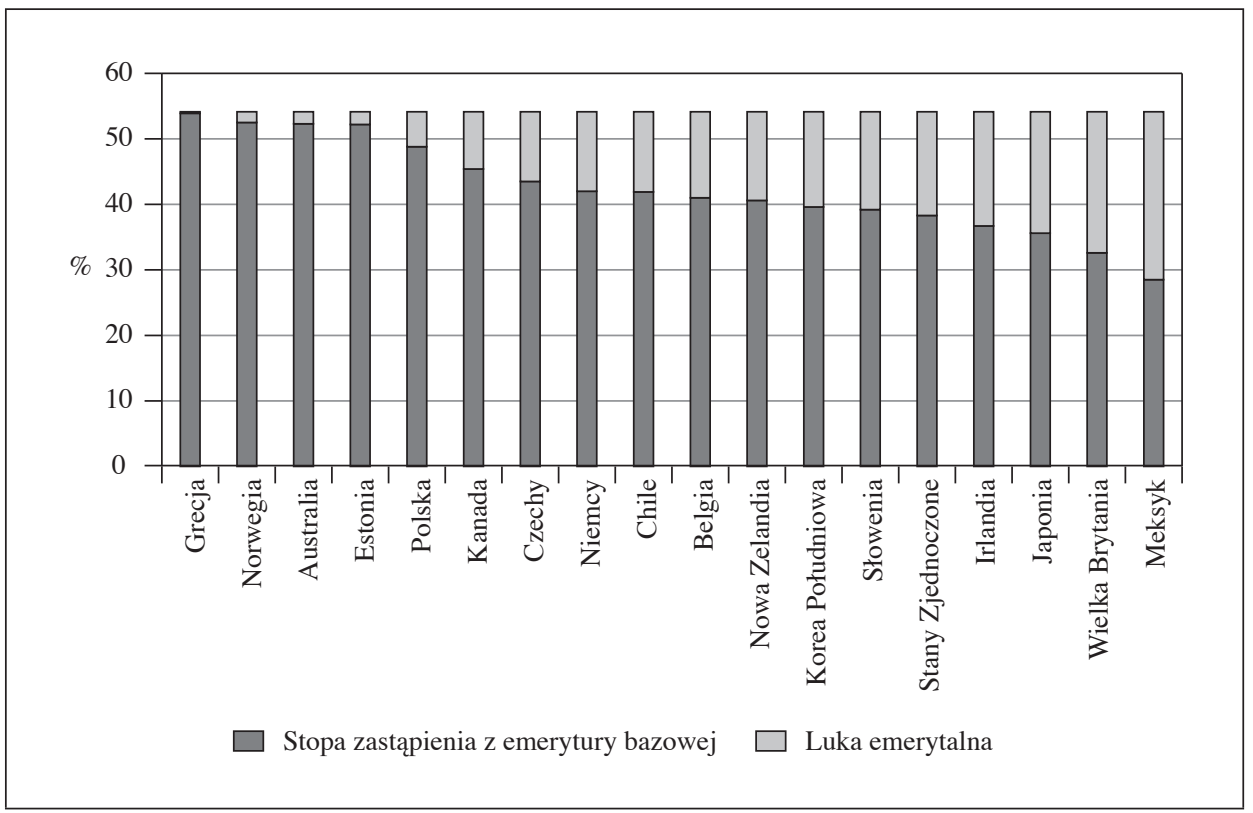

Objaśnienia: na rysunku uwzględniono kraje cechujące się dodatnią wartością luki emerytalnej, tj. kraje, w których stopa zastąpienia brutto z powszechnego systemu emerytalnego jest niższa od średniej stopy zastąpienia dla wszystkich krajów OECD $(54,4 \%)$.

Rys. 2. Luka emerytalna w wybranych krajach OECD

Źródło: opracowanie własne na podstawie [OECD 2013, s. 193].

Ostatnia ze sformułowanych uwag ma szczególne znaczenie w przypadku Polski. O ile bowiem obecna wysokość stopy zastąpienia jest relatywnie wysoka $(48,8 \%)$, a rozmiary luki emerytalnej kształtują się na względnie niskim poziomie (ok. 5,6\%), to prognozy Komisji Europejskiej wskazują, że w przyszłości wielkość ta drastycznie wzrośnie [EUC 2012, s. 98]. Sytuacja ta wynikać będzie ze spadku teoretycznej stopy zastąpienia dla kolejnych pokoleń pracowników, będącej jednym z efektów strukturalnej reformy systemu emerytalnego z 1999 r. W modelowym scenariuszu ${ }^{1}$ do 2050 r. stopa zastąpienia z systemu bazowego spadnie w Polsce o 32,2 pkt proc. [EUC 2012, s. 335-336]. Spośród wszystkich krajów Unii Europejskiej jedynie w przypadku Grecji prognozowany jest większy spadek wysokości stopy zastąpienia.

${ }^{1}$ W scenariuszu tym obliczona została stopa zastąpienia dla mężczyzny, który był aktywny zawodowo przez 40 lat i uzyskiwał w tym czasie dochód na poziomie średniego wynagrodzenia. 


\section{Funkcjonowanie trzeciego filara systemu emerytalnego w Polsce}

Spadek stopy zastąpienia uczestników zreformowanego systemu emerytalnego nie jest zjawiskiem nieoczekiwanym, będącym nieprzewidzianą konsekwencją przeprowadzonej reformy. Co prawda, problematyka ta stała się przedmiotem ożywionych dyskusji dopiero w ostatnich latach, jednakże fakt zmniejszenia się przyszłych stóp zastąpienia w ramach systemu bazowego był znany już w chwili jego projektowania. Stąd też jednym z elementów reformy z 1999 r. było zainicjowanie w Polsce dobrowolnego trzeciego filara, którego zadaniem jest uzupełnienie dochodu uzyskiwanego z części obowiązkowej systemu [Dodatkowy system... 2014, s. 11].

Mając na uwadze główny cel opracowania, ograniczoną objętość tekstu, a także bogactwo piśmiennictwa poruszającego problematykę zasad funkcjonowania trzeciego filara systemu emerytalnego, zaniechano przeprowadzania gruntownego studium na ten temat. W celu weryfikacji postawionej hipotezy oraz realizacji sformułowanych we wstępie celów badań skoncentrowano się na wybranych aspektach funkcjonowania instrumentów dostępnych w ramach tego filara. Ponadto syntetycznie zaprezentowano również wybrane dane empiryczne obrazujące zakres wykorzystania analizowanych instrumentów.

Zindywidualizowane formy dobrowolnego oszczędzania na emeryturę (IKE i IKZE) prowadzone są na podstawie umowy zawieranej przez oszczędzającego $\mathrm{z}$ instytucją finansową. Z kolei PPE będące formą zbiorowego oszczędzania na przyszłą emeryturę funkcjonują na podstawie umowy zakładowej zawieranej przez pracodawcę z pracownikami (reprezentacją pracowników) oraz umowy pomiędzy pracodawcą a instytucją finansową, przy czym każdy pracownik indywidualnie podejmuje decyzję o uczestnictwie w PPE. Najważniejsze zasady korzystania $\mathrm{z}$ tych instrumentów przedstawiono w tabeli 3 .

Obniżanie się relatywnej wysokości świadczeń z obowiązkowego systemu emerytalnego powinno mieć wpływ na skłonność Polaków do gromadzenia dodatkowych oszczędności w ramach trzeciego filara. Jednakże zakres wykorzystania promowanych przez państwo dobrowolnych form oszczędzania na emeryturę jest znikomy. Szacuje się, że spośród ogółu osób aktywnych zawodowo ok. 5,1\% ma konta w IKE, a 3,3\% w IKZE [KNF 2015a, s. 25]. Środki w ramach PPE gromadzi z kolei ok. 2,4\% pracujących [KNF 2015b, s. 3].

Według danych Komisji Nadzoru Finansowego ${ }^{2}$ w 2014 r. IKE posiadało 824 tys. osób. W przeszłości liczba ta była większa - w 2007 r. prowadzonych

${ }^{2}$ Wszystkie informacje statystyczne przytoczone w tej części opracowania opierają się na danych KNF zawartych w: [Biuletyn... 2015, Dane ze sprawozdań dotyczqce IKE 2015, Dane ze sprawozdań dotyczqce IKZE 2015, KNF 2015a, KNF 2015b], a także raporcie [Dodatkowy system... 2014]. 
Tabela 3. Wybrane zasady funkcjonowania PPE, IKE oraz IKZE

\begin{tabular}{|c|c|c|c|c|}
\hline \multirow[b]{2}{*}{ Wyszczególnienie } & \multicolumn{2}{|c|}{ PPE } & \multirow[b]{2}{*}{ IKE } & \multirow[b]{2}{*}{ IKZE } \\
\hline & $\begin{array}{c}\text { składka } \\
\text { podstawowa }\end{array}$ & $\begin{array}{c}\text { składka } \\
\text { dodatkowa }\end{array}$ & & \\
\hline $\begin{array}{l}\text { Źródło finanso- } \\
\text { wania }\end{array}$ & $\begin{array}{l}\text { Środki praco- } \\
\text { dawcy }\end{array}$ & $\begin{array}{l}\text { Wynagrodzenie } \\
\text { netto }\end{array}$ & $\begin{array}{l}\text { Środki oszczę- } \\
\text { dzającego }\end{array}$ & $\begin{array}{l}\text { Środki oszczę- } \\
\text { dzającego }\end{array}$ \\
\hline $\begin{array}{l}\text { Limit wpłat } \\
\text { uprawniający } \\
\text { do skorzystania } \\
\text { z preferencji } \\
\text { podatkowych } \\
\text { w roku kalenda- } \\
\text { rzowym }\end{array}$ & $\begin{array}{l}7 \% \text { wynagrodze- } \\
\text { nia uczestnika }\end{array}$ & $\begin{array}{l}\text { 4,5-krotność } \\
\text { przeciętnego } \\
\text { prognozowanego } \\
\text { wynagrodzenia } \\
\text { miesięcznego } \\
\text { (2014 r. - } \\
16857 \text { zł) }\end{array}$ & $\begin{array}{l}\text { 3-krotność } \\
\text { przeciętnego } \\
\text { prognozowanego } \\
\text { wynagrodzenia } \\
\text { miesięcznego } \\
\text { (2014 r. - } \\
11238 \text { zł) }\end{array}$ & $\begin{array}{l}\text { 1,2-krotność } \\
\text { przeciętnego } \\
\text { prognozowanego } \\
\text { wynagrodzenia } \\
\text { miesięcznego } \\
(2014 \text { r. }- \\
4495,20 \text { zł })\end{array}$ \\
\hline \multirow[t]{3}{*}{$\begin{array}{l}\text { Preferencje } \\
\text { podatkowe }\end{array}$} & $\begin{array}{l}\text { Wpłata jest } \\
\text { kosztem uzyska- } \\
\text { nia przychodu } \\
\text { pracodawcy. } \\
\text { Nie jest wliczana } \\
\text { do wynagrodze- } \\
\text { nia stanowiącego } \\
\text { podstawę usta- } \\
\text { lania składek } \\
\text { na ubezpiecze- } \\
\text { nie społeczne. } \\
\text { Jest jednak } \\
\text { wliczana do przy- } \\
\text { chodu uczestnika } \\
\text { i obciążona podat- } \\
\text { kiem dochodo- } \\
\text { wym od osób } \\
\text { fizycznych }\end{array}$ & $\begin{array}{l}\text { Potrącana } \\
\text { z wynagrodzenia } \\
\text { netto }\end{array}$ & $\begin{array}{l}\text { Wpłaty opodatko- } \\
\text { wane podatkiem } \\
\text { dochodowym od } \\
\text { osób fizycznych } \\
\text { na zasadach } \\
\text { ogólnych }\end{array}$ & $\begin{array}{l}\text { Wpłaty zwol- } \\
\text { nione z podatku } \\
\text { dochodowego od } \\
\text { osób fizycznych }\end{array}$ \\
\hline & \multicolumn{3}{|c|}{$\begin{array}{l}\text { Wypłaty zwolnione z podatku dochodowego od osób } \\
\text { fizycznych }\end{array}$} & $\begin{array}{l}\text { Wypłaty } \\
\text { opodatkowane } \\
\text { zryczałtowa- } \\
\text { nym podatkiem } \\
\text { dochodowym od } \\
\text { osób fizycznych } \\
(10 \%)\end{array}$ \\
\hline & \multicolumn{4}{|c|}{$\begin{array}{l}\text { Zysk z inwestowania zgromadzonych środków nie podlega opodatkowaniu } \\
\text { podatkiem od zysków kapitałowych } \\
\text { Zgromadzone środki podlegają dziedziczeniu i są zwolnione z podatku od } \\
\text { spadków }\end{array}$} \\
\hline
\end{tabular}


cd. tabeli 3

\begin{tabular}{|c|c|c|c|c|}
\hline \multirow[b]{2}{*}{ Wyszczególnienie } & \multicolumn{2}{|c|}{ PPE } & \multirow[b]{2}{*}{ IKE } & \multirow[b]{2}{*}{ IKZE } \\
\hline & $\begin{array}{c}\text { składka } \\
\text { podstawowa }\end{array}$ & $\begin{array}{c}\text { składka } \\
\text { dodatkowa }\end{array}$ & & \\
\hline $\begin{array}{l}\text { Warunki } \\
\text { wypłaty }^{\mathrm{a}}\end{array}$ & \multicolumn{2}{|c|}{$\begin{array}{l}\text { - na wniosek uczestnika po osiągnię- } \\
\text { ciu przez niego } 60 \text { lat } \\
\text { - na wniosek uczestnika po ukończe- } \\
\text { niu przez niego } 55 \text { lat i uzyskaniu } \\
\text { prawa do emerytury } \\
\text { - w przypadku ukończenia przez } \\
\text { uczestnika } 70 \text { lat, jeżeli wcześniej } \\
\text { nie wystąpił on z wnioskiem } \\
\text { o wypłatę środków }\end{array}$} & \begin{tabular}{|l} 
Na wniosek: \\
- po osiągnięciu \\
60 lat \\
- po nabyciu \\
uprawnień \\
emerytalnych \\
i ukończeniu \\
55 lat pod \\
warunkiem \\
dokonywa- \\
nia wpłat \\
co najmniej \\
w 5 latach \\
kalendarzo- \\
wych lub \\
dokonania co \\
najmniej 50\% \\
wpłat nie póź- \\
niej niż 5 lat \\
przed złoże- \\
niem wniosku
\end{tabular} & $\begin{array}{l}\text { Na wniosek po } \\
\text { osiągnięciu } 65 \text { lat } \\
\text { oraz pod warun- } \\
\text { kiem dokonywa- } \\
\text { nia wpłat co naj- } \\
\text { mniej w } 5 \text { latach } \\
\text { kalendarzowych }\end{array}$ \\
\hline Forma wypłaty & \multicolumn{4}{|c|}{ Jednorazowa lub w ratach } \\
\hline
\end{tabular}

a Podano standardowe warunki wypłaty, pomijając możliwość wcześniejszych wypłat (wypłata transferowa, zwrot środków oraz wypłaty dla osób dziedziczących).

Źródło: opracowanie własne.

było ponad 915 tys. IKE, jednakże w latach 2008-2010, na fali spadku zaufania do instytucji finansowych w związku z globalnym kryzysem, zamkniętych zostało ponad 100 tys. tego typu kont. Liczba osób posiadających IKZE na koniec 2014 r. wynosiła 528 tys., co - biorąc pod uwagę, że instrument ten jest dostępny dopiero od 2012 r. - jest wynikiem mogącym świadczyć o wzroście przezorności emerytalnej Polaków, a także o atrakcyjności tej formy oszczędzania. Tak optymistyczny wniosek okazuje się jednak niezasadny, jeżeli wziąć pod uwagę informacje dotyczące liczby rachunków aktywnych w ostatnim roku (tj. takich, na które wpłynęła składka). W przypadku IKZE jest to zaledwie 86 tys. kont (16\% ogółu). Podobnie jest w przypadku IKE - w 2014 r. aktywnych było niewiele ponad 262 tys. kont (32\%). Łączna wartość aktywów zgromadzonych na IKE na koniec grudnia $2014 \mathrm{r}$. wynosiła 5030,5 mln zł i była o 17,4\% wyższa w stosunku do roku poprzedniego. Na każdego uczestnika IKE przypadało więc średnio 6101 zł zgromadzonych oszczędności, w przypadku IKZE było to natomiast 560 zł. Tak niska średnia 
wynika głównie z istnienia nieaktywnych kont o bardzo niskim lub zerowym saldzie. Jeżeli odnieść sumę środków zgromadzonych na IKE i IKZE jedynie do liczby aktywnych kont, wielkości te wynoszą odpowiednio 19039 zł oraz 3414 zł. Suma wszystkich wpłat dokonanych na IKE i IKZE w całym 2014 r. wynosiła odpowiednio 909,0 mln zł oraz 201,9 mln zł. Oznacza to, że przeciętny posiadacz IKE wpłacił na swoje konto 3440 zł (wzrost w stosunku do 2013 r. o 312 zł), a posiadacz IKZE - 2333 zł (wzrost w stosunku do 2013 r. o 1202 zł). Warto zauważyć, że wartości te stanowią zaledwie $31 \%$ (IKE) oraz 52\% (IKZE) maksymalnych limitów wpłat objętych preferencjami podatkowymi (por. tabela 3).

W 2014 r. prowadzonych było 1064 pracowniczych programów emerytalnych. Przy czym w latach 2005-2010 liczba PPE zwiększała się w tempie kilkudziesięciu programów rocznie, osiągając maksymalną wartość 1116, a począwszy od 2011 r. wartość ta z roku na rok maleje. Co ciekawe, wbrew powszechnej opinii, jakoby warunki i koszty prowadzenia PPE powodowały, że programy te są prowadzone wyłącznie przez duże przedsiębiorstwa, największą ich liczbę zarejestrowano w przypadku małych i średnich przedsiębiorstw (50,3\% ogółu PPE). Liczba uczestników PPE z roku na rok rośnie, obecnie środki w ramach PPE posiada ponad 381 tys. osób, jednakże $15,4 \%$ z nich to uczestnicy bierni, tj. tacy, w przypadku których w ostatnim roku nie odprowadzono żadnej składki. Wskaźnik uczestnictwa w PPE obliczony jako stosunek liczby uczestników PPE, na rzecz których wznoszone są składki, do całkowitej liczby osób zatrudnionych u pracodawców prowadzących PPE wynosi ok. 74\%. Całkowita wartość aktywów zgromadzonych w PPE systematycznie rośnie ${ }^{3}-$ w 2014 r. wyniosła ponad 9867,8 mln zł (wzrost w stosunku do 2013 r. o 14\%). Łączna wartość składek odprowadzanych na PPE wynosiła w 2014 r. 1209 mln zł, jednakże jedynie 3\% tej kwoty (36,3 mln zł) stanowiły składki dobrowolne. Oznacza to, że w ujęciu jednostkowym konto przeciętnego uczestnika PPE w 2014 r. zostało zasilone kwotą równą 3077 zł z tytułu składki podstawowej oraz 95 zł z tytułu składki dodatkowej. Obliczona w analogiczny sposób średnia wartość aktywów przypadających na jednego uczestnika wynosi 25,9 tys. zł.

\section{Instrumenty trzeciego filara polskiego systemu emerytalnego w zabezpieczaniu przed ryzykiem starości}

Przegląd zasad funkcjonowania oraz analiza zakresu wykorzystania dodatkowych form oszczędzania dostępnych w ramach trzeciego filara prowadzą do

${ }^{3}$ Ze względu na fakt, że zdecydowana większość uczestników PPE nadal znajduje się w fazie akumulacji środków, sytuacja ta jest jednak oczywista i nie stanowi podstawy do formułowania twierdzeń o wzroście znaczenia PPE jako instrumentu dodatkowego zabezpieczenia emerytalnego. 
sformułowania szeregu zastrzeżeń dotyczących możliwości skutecznego zabezpieczania przed ryzykiem starości przez te instrumenty. W pierwszej kolejności zwraca uwagę znikome wykorzystanie tego typu instrumentów. Z przeprowadzonych analiz wynika, że łączna wartość środków zgromadzonych w trzecim filarze wynosi 15,2 mld zł, a liczba osób posiadających oszczędności w PPE, IKE lub IKZE wynosi ok. 1,7 mln, przy czym jedynie 670 tys. spośród tych osób poczyniło w 2014 r. jakiekolwiek oszczędności emerytalne. Odniesienie tej wielkość do liczby osób pracujących w gospodarce - 14,563 mln osób [GUS 2015a, s. 25], prowadzi do stwierdzenia, że statystycznie jedynie co 22 osoba pracująca dokonała w 2014 r. dobrowolnej wpłaty na poczet przyszłej emerytury.

W obliczu niewielkiego stopnia wykorzystania dobrowolnych form oszczędzania na emeryturę niepokojącym zjawiskiem jest także obserwowana w ostatnich latach stagnacja dotycząca trzeciego filara. Co prawda wartość środków zgromadzonych na IKE, IKZE i PPE z roku na rok systematycznie rośnie, ale wzrost ten nie jest adekwatny do rzeczywistych potrzeb. Zaskakujące jest to, że pomimo rozszerzania oferty produktowej instytucji finansowych oferujących możliwość gromadzenia środków w formie różnych instrumentów finansowych nastąpił spadek liczby prowadzonych IKE. Co najmniej alarmujące jest zmniejszenie się liczby prowadzonych PPE, które w ogólnych statystykach przysłania powolny wzrost liczby pracowników objętych tego typu programami. Odnotować należy także, że wprowadzone w 2014 r. zmiany w zasadach funkcjonowania IKZE nie wpłynęły istotnie na zwiększenie liczby nowo otwieranych kont i wzrost wartości dokonywanych wpłat.

Niewielki zakres wykorzystania instrumentów trzeciego filara oraz stagnacja ich rozwoju nie powinny być jednak traktowane jako przyczyny niskiej skuteczności trzeciego filara w zabezpieczaniu przed ryzykiem starości. Okoliczności te są jedynie objawami ułomności funkcjonowania całego dodatkowego systemu zabezpieczenia emerytalnego w Polsce. Zasadniczo wynikają one z dwóch nakładających się na siebie czynników - małej atrakcyjności dostępnych instrumentów oraz niskiej świadomości emerytalnej Polaków.

Na ogół mała atrakcyjność instrumentów dodatkowego zabezpieczenia emerytalnego utożsamiana jest ze zbyt niskim poziomem zachęt kierowanych do oszczędzających. Rozumowanie takie opiera się na twierdzeniu, że skłonność do oszczędzania wzrasta wraz ze zwiększaniem skali zachęt fiskalnych, a gdy bodźce stricte fiskalne okazują się zbyt słabe - innych zachęt o charakterze ekonomicznym, takich jak np. bezpośrednie dopłaty do programów oszczędnościowych (matching contributions) [Pieńkowska-Kamieniecka i Ostrowska-Dankiewicz 2013, s. 120]. Konstrukcja systemu zachęt do dodatkowego oszczędzania na emeryturę poza oczekiwaniami oszczędzających musi jednak uwzględniać również realne możliwości ich finansowania, będące pochodną polityki fiskalnej państwa. W praktyce 
od samej wielkości zachęt dużo istotniejsza jest zatem ich konstrukcja. Analiza systemu zachęt fiskalnych oferowanych w ramach IKE, IKZE oraz PPE prowadzi do sformułowania następujących uwag dotyczących ich budowy:

- funkcjonujący w ramach IKE oraz PPE schemat opodatkowania, w którym opodatkowaniu podlega składka, a zwolnione są dochody od zysków kapitałowych oraz wypłacane świadczenia (schemat TEE: tax, exempt, exempt), z punktu widzenia oszczędzającego stanowi dużo mniejszy bodziec do oszczędzania niż schemat, w którym opodatkowaniu podlegają świadczenia, a dochody od zysków kapitałowych i składki są zwolnione z podatku (schemat EET: exempt, exempt, tax);

- brak ujednoliconego, spójnego z powszechnym wiekiem emerytalnym, wieku uprawniającego do wypłaty świadczeń z poszczególnych instrumentów trzeciego filara. Ponadto forma opodatkowania świadczeń z IKZE oraz zwolnienie z podatku dochodowego świadczeń z IKE i PPE nie zachęcają oszczędzających do dokonywania wypłat w formie rent dożywotnich. W efekcie istnieje zagrożenie, że zgromadzone środki zostaną wykorzystane na cele inne niż emerytalne [Dodatkowy system... 2014, s. 43];

- zwolnienie składki podstawowej ze składki na ubezpieczenie społeczne oraz możliwość jej wliczenia w koszty działalności przedsiębiorstwa nie są wystarczająco atrakcyjne dla pracodawców rozważających założenie PPE;

- w przypadku składki dodatkowej na PPE jedyną zachętą jest zwolnienie z podatku od zysków kapitałowych, będące słabym bodźcem do dodatkowego oszczędzania, szczególnie w sytuacji, gdy wiąże się ono z ograniczeniem możliwości dysponowania zainwestowanymi środkami;

- jednakowe dla wszystkich oszczędzających (liniowe) zwolnienie z podatku dochodowego składek na IKZE powoduje, że instrument ten nie jest atrakcyjny dla uboższej części społeczeństwa.

W odniesieniu do PPE można sformułować również zastrzeżenia dotyczące stopnia skomplikowania procedury ich rejestracji w KNF, a także treści przepisów, które uniemożliwiają pracodawcom elastyczne kształtowanie warunków uczestnictwa poszczególnych pracowników, co utrudnia wykorzystanie PPE jako instrumentu aktywnego zarządzania kapitałem ludzkim [Dodatkowy system... 2014, s. 41]. Ponadto należy zwrócić uwagę, że mnogość dostępnych w ramach IKE i IKZE form oszczędzania powoduje, że różnice między tymi instrumentami nie są wystarczająco jasne i zrozumiałe dla oszczędzających. Sytuację tę dodatkowo utrudnia brak obowiązków sprawozdawczych dotyczących efektywności IKE i IKZE, co powoduje, że oszczędzający nie mają możliwości porównania posiadanego produktu $\mathrm{z}$ ofertą konkurencji.

Poziom świadomości emerytalnej ma kluczowe znaczenie dla powszechności dodatkowych instrumentów zabezpieczenia emerytalnego. Nawet najlepiej skonstruowany system zachęt nie zapewni bowiem szerokiego ich wykorzystania, jeżeli 
potencjalni oszczędzający nie będą świadomi istnienia luki emerytalnej oraz nie będą wiedzieć, z jakich produktów mogą korzystać, aby podnieść poziom dochodu po zaprzestaniu aktywności zawodowej [Rutecka 2014, s. 11]. Obraz świadomości emerytalnej Polaków przybliżają rezultaty empirycznych badań opinii [Polacy... 2010, Portret... 2012, Zachowania... 2014, Wpływ reformy... 2014]. Zasadniczym wnioskiem płynącym z tych badań jest stwierdzenie, że zarówno wiedza dotycząca systemu emerytalnego, jak i poziom świadomości emerytalnej Polaków kształtują się na niskim poziomie. Zaznaczyć należy jednak, że na skutek ożywionych dyskusji na forum publicznym, które towarzyszyły zmianom w systemie emerytalnym wprowadzonym w latach 2011-2014, sytuacja ta w ostatnich latach stopniowo się poprawia [Portret... 2012, s. 8-9; Dodatkowy system... 2014, s. 42; Wptyw reformy... 2014, s. 2-4].

Niski poziom edukacji emerytalnej powoduje, że większość Polaków (ponad 60\%) nie wykazuje zainteresowania długoterminowym oszczędzaniem z myślą o przyszłej emeryturze ${ }^{4}$ [Wpływ reformy... 2014, s. 2]. Wynika to z powszechnie panującego przekonania, że to państwo jest odpowiedzialne za świadczenia emerytalne i to ono w przyszłości zatroszczy się o dochody przyszłych emerytów [KNF 2015a, s. 26]. Brak wystarczającej wiedzy emerytalnej i finansowej utrudnia również wybór odpowiednich instrumentów zabezpieczenia emerytalnego oraz prowadzi do występowania zjawiska tzw. misselingu (niedopasowania produktu do potrzeb nabywcy), co powoduje spadek zaufania do całego dodatkowego systemu zabezpieczenia emerytalnego [Rutecka 2014, s. 11]. Warto również odnotować, że według badanych głównym powodem braku gromadzenia środków na przyszłą emeryturę jest zbyt niski poziom bieżących dochodów [Polacy... 2010, s. 8]. Jednocześnie z danych GUS wynika, że udział wydatków w dochodach rozporządzalnych gospodarstw domowych w latach 2004-2014 zmniejszył się z 94,5\% do $80,5 \%$ [GUS 2015b, s. 41]. Obiektywnie sytuacja ta powinna więc wpływać na wzrost możliwości dodatkowego oszczędzania.

Niezależnie od sformułowanych powyżej zastrzeżeń dotyczących funkcjonowania trzeciego filara polskiego systemu emerytalnego jego całościowa analiza prowadzi do stwierdzenia, że dostępne w jego ramach instrumenty nie tworzą spójnego systemu, który można by określić mianem dodatkowego systemu emerytalnego. W szczególności zwraca uwagę niewielki stopień powiązania ze sobą poszczególnych form oszczędzania oraz wspomniany brak jednolitego wieku uprawniającego do wypłaty środków. Co więcej, w obecnej formie trzeci filar ogranicza się wyłącznie do oszczędzania na emeryturę, brak natomiast jakichkolwiek promowanych przez państwo rozwiązań dotyczących wypłaty zgromadzonych środków. W efekcie powoduje to, że trzeci filar nie zabezpiecza oszczę-

${ }^{4}$ Co ciekawe, wbrew oczekiwaniom rezultaty badań wskazują, że skłonność Polaków do oszczędzania na emeryturę maleje wraz z wiekiem [Wpływ reformy... 2014, s. 3-4]. 
dzających przed zagrożeniami związanymi z drugą fazą ryzyka starości, w tym w szczególności przed ryzykiem długowieczności.

\section{Podsumowanie i wnioski}

Jednym z efektów strukturalnej reformy systemu emerytalnego z 1999 r. jest długookresowy spadek stopy zastąpienia z bazowego systemu emerytalnego dla kolejnych roczników przechodzących na emeryturę. W tej sytuacji najważniejszym zadaniem stawianym trzeciemu filarowi polskiego sytemu emerytalnego jest wypełnienie powiększającej się luki emerytalnej. Analiza dotychczasowego funkcjonowania instrumentów dostępnych w ramach tego filara wykazała jednak, że nie są one wystarczająco atrakcyjne dla potencjalnych oszczędzających. Powoduje to, że są one wykorzystywane przez niewielu oszczędzających i na małą skalę. Jeśli chodzi o sformułowany we wstępie problem badawczy, głównym wnioskiem płynącym z przeprowadzonych analiz jest więc stwierdzenie, że instrumenty dostępne obecnie $w$ ramach trzeciego filara nie zabezpieczają skutecznie przed ryzykiem starości. Oznacza to więc, że nie ma podstaw do odrzucenia przyjętej hipotezy badawczej, zgodnie z którą w celu skutecznego zarządzania ryzykiem starości niezbędne jest wprowadzenie zmian w trzecim filarze polskiego systemu emerytalnego.

Konsekwencją stwierdzenia braku podstaw do odrzucenia przyjętej hipotezy badawczej jest sformułowanie wniosków wynikających z przeprowadzonych analiz. Wnioski te mają dwojaki charakter:

1) obiektywnych spostrzeżeń dotyczących funkcjonowania poszczególnych instrumentów dostępnych w ramach trzeciego filara (IKE, IKZE, PPE), które zostały sformułowane $\mathrm{w}$ toku prowadzonych rozważan;

2) wskazanych poniżej sugestii w zakresie potencjalnych kierunków zmian w trzecim filarze systemu emerytalnego, które w przeważającej mierze zostały sformułowane na podstawie przeglądu różnych propozycji jego modyfikacji [Porównanie... 2011, World Bank 2014, Barr i Diamond 2014, Dodatkowy system... 2014, Kawalec, Błażuk i Kurek 2015, Rutecka 2015]. Zalecenia te obejmują:

- uproszczenie konstrukcji indywidualnych form oszczędzania - jedno wieloproduktowe rozwiązanie w miejsce doczasowych IKE i IKZE (alternatywą proponowaną przez KNF jest wprowadzenie kolejnego produktu - emerytalnego konta oszczędnościowego, mającego funkcjonować równolegle z już istniejącymi);

- wprowadzenie powszechności PPE przez zastosowanie klauzuli automatycznego zapisu pracowników (auto-enrollment) z opcją wyjścia (opt-out);

- modyfikację PPE w kierunku przybliżenia w czasie korzyści podatkowych dla uczestnika w celu zwiększenia bodźców zachęcających do oszczędzania (model EET lub ETT w miejsce dotychczasowego TEE); 
- nałożenie na pracodawców (wszystkich lub wybrane grupy) obowiązku tworzenia PPE lub partycypacji w programach międzyzakładowych o charakterze ogólnokrajowym;

- zainicjowanie systemu jednorazowych lub systematycznych dopłat bezpośrednich do oszczędności emerytalnych;

- wprowadzenie degresywnych odpisów od podatku w związku z korzystaniem z instrumentów trzeciego filara, tak aby wzmocnić zachęty kierowane do uboższej części społeczeństwa;

- wprowadzenie preferencyjnych zasad opodatkowania wypłat środków zgromadzonych w instrumentach trzeciego filara w formie rent dożywotnich bądź stworzenie nowego produktu rentowego oferowanego przez instytucje publiczną.

Niemniej istotna od sugerowanych zmian w funkcjonowaniu instrumentów trzeciego filara jest również edukacja emerytalna społeczeństwa [Rutecka 2014, s. 265]. Warunkami rozwoju dodatkowego systemu emerytalnego są bowiem zarówno istnienie atrakcyjnej i przejrzystej oferty produktów oszczędnościowych, jak i uświadomiona społeczeństwu potrzeba ich wykorzystywania. Część ciężaru edukacji finansowej i emerytalnej mogą wziąć na siebie podmioty prywatne (banki, zakłady ubezpieczeń itp.), które są zainteresowane promowaniem oferowanych przez siebie produktów. W tym kontekście ciekawą propozycją jest wprowadzenie systemu zachęt podatkowych (np. w zakresie obniżenia stawki podatku VAT) dla instytucji reklamujących produkty trzeciego filara [Porównanie... 2011, s. 42]. Skuteczna akcja edukacyjna wymaga również współudziału instytucji rynku finansowego, takich jak NBP, KNF, Rzecznik Finansowy itp. Działalność edukacyjna tych podmiotów powinna być ukierunkowana na przedstawianie korzyści wynikających z długiego okresu i systematyczności oszczędzania oraz powinna być skierowana w szczególności do osób rozpoczynających pracę [KNF 2015a, s. 26].

\section{Literatura}

Arrow K. [1979], Eseje z teorii ryzyka, PWN, Warszawa.

Barr N., Diamond P. [2014], Reformy systemu emerytalnego, Krótki przewodnik, PTE, Warszawa.

Biuletyn roczny. Rynek PPE 2014 [2015], KNF, http://www.knf.gov.pl/opracowania/ rynek_emerytalny/dane_o_rynku/rynek_ppe_ike/Dane_roczne/roczne_ppe.html (data dostępu: 21.11.2015).

Czekaj J., Dresler Z. [2006], Zarzq̨dzanie finansami przedsiębiorstw. Podstawy teorii, Wydawnictwo Naukowe PWN, Warszawa.

Dane ze sprawozdań dotyczqce IKE [2015], KNF, http://www.knf.gov.pl/opracowania/ rynek_emerytalny/dane_o_rynku/rynek_ppe_ike/Dane_IKE/dane_ike.html (data dostępu: 21.11.2015). 
Dane ze sprawozdań dotyczqce IKZE [2015] KNF, http://www.knf.gov.pl/opracowania/ rynek_emerytalny/dane_o_rynku/rynek_ppe_ike/Dane_IKZE/dane_ikze.html (data dostępu: 21.11.2015).

Dodatkowy system emerytalny w Polsce - diagnoza i rekomendacje zmian [2014], red. J. Rutecka, Towarzystwo Ekonomistów Polskich, Warszawa.

EUC [2012], Pension Adequacy in the European Union. 2010-2050, Report prepared jointly by the Directorate-General for Employment, Social Affairs and Inclusion of the European Commission and the Social Protection Committee, Publications Office of the European Union, Luxembourg.

Góra M. [2003], System emerytalny, PWE, Warszawa.

GUS [2015a], Pracujacy w gospodarce narodowej w 2014 r., Warszawa, http://stat.gov.pl/ download/gfx/portalinformacyjny/pl/defaultaktualnosci/5474/7/11/1/pracujacy_w_ gospodarce_narodowej_w_2014.pdf (data dostępu: 23.11.2015).

GUS [2015b], Budżety gospodarstw domowych w 2014 r., Warszawa, http://stat.gov.pl/ download/gfx/portalinformacyjny/pl/defaultaktualnosci/5486/9/9/1/publikacja.pdf (data dostępu: 2.12.2015).

Handshke J., Łyskawa K., Ratajczak J. [2005], Ryzyko emerytalne w systemie zabezpieczenia na starość [w:] Społeczne aspekty ubezpieczenia, red. T. Szumlicz, SGH, Warszawa.

Jurek Ł. [2012], Ekonomia starzejącego się społeczeństwa, Difin, Warszawa.

Kawalec S., Błażuk K., Kurek M. [2015], Jak mobilizować dodatkowe oszcz̨̨ności emerytalne?, Capital Strategy, Warszawa.

KNF [2015a], Indywidualne Konta Emerytalne oraz Indywidualne Konta Zabezpieczenia Emerytalnego w 2014 r., Warszawa http://www.knf.gov.pl/Images/Raport_IKE_ IKZE_2014_tcm75-41353.pdf (data dostępu: 20.11.2015).

KNF [2015b], Pracownicze programy emerytalne w 2014 r., Warszawa, http://www.knf. gov.pl/Images/RAPORT_PPE_w_2014_tcm75-41984.pdf (data dostępu: 20.11.2015).

Knight F. [1921], Risk, Uncertainty and Profit, Houghton Mifflin, Boston-New York.

OECD [2013], Pensions at a Glance 2013: OECD and G20 Indicators, http://www. oecd.org/pensions/public-pensions/OECDPensionsAtAGlance2013.pdf (data dostępu: 1.12.2015).

Philip F. [1967], Risiko und Risikpolitik, C.E. Poeschel Verlag, Stuttgart.

Pieńkowska-Kamieniecka S., Ostrowska-Dankiewicz A. [2013], Dopłaty do dobrowolnych oszczędności emerytalnych - ocena skuteczności rozwiqzań na przykładzie Niemiec i Nowej Zelandii, „Wiadomości Ubezpieczeniowe”, nr 3.

Polacy o dodatkowym oszczędzaniu na emeryture [2010], Komunikat CBOS nr BS/77/2010, Warszawa, http://www.cbos.pl/SPISKOM.POL/2010/K_077_10.PDF (data dostępu: 29.11.2015).

Porównanie systemów dodatkowego zabezpieczenia emerytalnego w Polsce oraz wybranych krajach Unii Europejskiej [2011], Raport PwC Polska dla Izby Zarządzających Funduszami i Aktywami, http://www.pwc.pl/en/publikacje/raport_pwc_porownanie systemow_dodatkowego_zabezpieczenia_emerytalnego.pdf (data dostępu: 6.12.2015).

Portret finansowy Polaków 2012. Plany na 2013 rok [2012], Deutshe Bank, Warszawa, https://www.deutschebank.pl/file-5865472.bdoc (data dostępu: 30.11.2015).

Poteraj J. [2011], Metoda ubezpieczeniowa w zarzqdzaniu ryzykiem starości [w:] Ubezpieczenia gospodarcze i społeczne. Wybrane zagadnienia ekonomiczne, red. W. Sułkowska, Wolters Kluwer, Warszawa. 
Rowe W.A. [1977], An Anatomy of Risk, John Wiley and Sons, New York.

Rutecka J. [2012], Zakres redystrybucji dochodowej w ubezpieczeniowym systemie emerytalnym, SGH, Warszawa.

Rutecka J. [2014], Dodatkowe zabezpieczenie emerytalne - charakterystyka i czynniki rozwoju, Prace Naukowe Uniwersytetu Ekonomicznego we Wrocławiu, nr 342, Wrocław, https://doi.org/10.15611/pn.2014.342.24.

Rutecka J. [2015], Relokacja czy nowe oszczędności? O efektach zachęt podatkowych $w$ dodatkowym oszczędzaniu na starość w Polsce, „Rozprawy Ubezpieczeniowe”, nr 18(1).

Skov N.A. [1991], Finanse i zarządzanie. Amerykańskie propozycje dla polskich firm prywatnych, International School of Management, Warszawa.

Szczepański M. [2014], Zarzqdzanie ryzykiem długowieczności w polskim systemie emerytalnym, Zeszyty Naukowe Uniwersytetu Szczecińskiego, nr 802, Finanse, Rynki Finansowe, Ubezpieczenia, nr 65, Szczecin.

Szumlicz T. [2005], Ubezpieczenie społeczne. Teoria dla praktyki, Oficyna Wydawnicza Branta, Bydgoszcz-Warszawa.

Willet A.H. [1951], The Economic Theory of Risk Insurance, University of Pennsylvania Press, Philadelphia.

Williams A., Smith M., Young P. [2002], Zarzqdzanie ryzykiem a ubezpieczenia, Wydawnictwo Naukowe PWN, Warszawa.

World Bank [2014], Poland: Saving for Growth and Prosperous Aging. Country Economic Memorandum, World Bank, http://documents.worldbank.org/curated/ en/2014/06/20291843/poland-country-economic-memorandum-saving-growthprosperous-aging (data dostępu: 6.12.2015).

Wpływ reformy OFE na oszczędzanie w III Filarze [2014], Raport z badań, CBOS, Warszawa, http://www.dobraemerytura.org/media/uploads/raport/Raport_CBOS_dla_ IZFiA_III_filar.pdf (data dostępu: 29.11.2015).

Zachowania finansowe Polaków dotyczqce oszczędzania na emeryturę [2014], Badanie TNS Polska na zlecenie Nordea PTE SA, http://www.nordeapolska.pl/koniec-konsumpcji-czas-na-oszczedzanie (data dostępu: 30.11.2015).

\section{Managing Old-age Risk and a Supplementary Pension System in Poland} (Abstract)

The article examines the use of a supplementary pension scheme in Poland to insure against old-age risk. The following hypothesis was verified: In order to effectively manage the risks that attend aging, the rules governing third pillar instruments in Poland must be changed. To this end, the old-age risk was characterised and the rules governing the third pillar instruments were analysed, as were the current state and use of those instruments. No grounds to reject the research hypothesis were found, though the desirable direction of changes in the functioning of these instruments is indicated. In addition, the importance of education about pension systems is emphasised.

Keywords: pension system, replacement rate, pension gap, third pillar. 